My heart is turning home again to fair Nebraskee

To the land of pork and plenty, to the best town in the state,

Where we ne'er will feed the fislies

With what we've taken on our plate.

Well-educated, perceptive Americans from Benjamin Franklin and Thomas Jefferson to the present have visited Europe with a genuine sense of appreciation. However, little note has been taken of the level of appreciation achieved by the average citizen. We have here a diary of an American tourist in Europe written in 1912; one that could just as well have been written in 1963. The grand memories remain and may become grander; but Europe, it seems, doesn't quite live up to the original expectations. The closing poems of the diary of Florence Binns express an evident sense of relief at the return to the home of the American eagle-the best kind.

\title{
Few Recall 'Infidel' Town Of Salubria
}

By George Shane

From The Des Moines Sunday Register

Oct. 7, 1951

Farmington, Iowa-It is for the most part only the older residents of Farmington who remember today the story of Iowa's so-called "Infidel colony" which sprang up near here more than a century ago.

This was the colony of "The First Society of Free Enquirers," and the town name was Salubria.

It was founded by one of the most widely known ministers and intellectuals of the day, Abner Kneeland of New England, who came here to encourage formation of that unique settlement of fellow thinkers and their families.

The story of Iowa's other colonies and movements, religious or intellectual-the story of the Mormon trail, the Icarian colony of French at Corning, the Amanas, have been well publicized through the years.

But the town of. Salubria and Abner Kneeland, with his 
controversial ideas, are little remembered today despite the fact that in the 1840's the colony and its leader enjoyed a national fame.

Today an archeologist would need to search through the cornfields about two miles south of Farmington to find a trace of the foundations on which stood the cluster of little houses at Salubria.

The settlement was founded in 1839 on timbered land north of the Des Moines river banks. Kneeland's death in 1844 was the final blow to the village of roughly built houses and cabins.

The colonists' way of life had been somewhat primitive, and yet those who later wrote of Salubria recalled the quality of the libraries of books and papers found in every home.

Kneeland is buried at Farmington. Events of his life are recorded in New England's histories, and his relations to early Iowa history were comprehensively described by Mrs. B. Whitcomb in the Annals of Iowa for April, 1904.

Kneeland's trial for blasphemy was fought through the courts at Boston, Mass., and in 1838 he received a sentence of 60 days.

Kneeland was convicted for an article in The Investigator, widely circulated journal which he founded and published. Criticizing the Universalists, he differed with their belief in a God, in the divinity of Christ and declared.his. own belief that "... no individual life is, ever was, or ever will be eternal."

When Kneeland was imprisoned, a storm of protest arose, and among those who petitioned the governor for Kneeland's release were William Channing, A. Bronson Alcott, Theodore Parker, George Ripley, William Garrison, and Emerson.

Kneeland served his sentence but the International Cyclopedia noted that there was no prosecution under the blasphemy statute after the Kneeland case and that "public opinion upon the freedom of the press has greatly changed."

A year after his sentence, Kneeland, then a man of 65, arrived in the far away Territory of Iowa as a leader in Salubria, a colony which would be dedicated to freedom of inquiry. 
But the hard work of clearing the land and making a living from the soil limited Kneeland's activities.

He lectured in Farmington, Bonaparte, Bentonsport and Keosauqua, but the fears of the Iowa band revivalists that Kneeland might substitute Paine's "Age of Reason" for the Bible were never realized.

Gradually the several families of followers who had come from the east under the leadership of Kneeland moved into Farmington or nearby farms and joined the churches and Sunday schools which their neighbors attended.

The Van Buren county history of 1878 said "the severity of judgment which at one time was heavily against him" had softened and "what was sterling in his character is now respected in his memory."

In the old histories Kneeland lives as one of the early American thinkers and editors who did the most to make possible free expression of thought and fortify the freedom of the American press. He was imprisoned for blasphemy and defended by Ralph Waldo Emerson.

Kneeland was a Baptist and then a Universalist minister before joining other New England thinkers in pantheistic concepts. He was married four times and had 12 children.

Many of his descendants live in Iowa and other midwest and eastern states today.

A granddaughter, Mrs. Grace Forgrave, 73, lives here [1951] and is now gathering together material on Kneeland's life.

So far as is known, all descendants of the original Salubria colonists are affiliated with churches. Mrs. Forgrave is a member of the Congregational church, and she explained that the designation "Infidel's colony," is far from an accurate one.

In his own statements Kneeland had said he was not an atheist but a pantheist. But feeling in the 1840's often was strongly expressed against "the infidel colony.".

In 1843, when the revival movement of "the Iowa band" was strong, one of that group's leaders wrote that attempts were being made at Salubria to "substitute Paine's 'Age of Reason' for the family Bible, the dance for the prayer meeting and the holiday for the Sabbath." 
Copyright of Annals of Iowa is the property of State of Iowa, by \& through the State Historical Society of Iowa and its content may not be copied or emailed to multiple sites or posted to a listserv without the copyright holder's express written permission. However, users may print, download, or email articles for individual use. 